GRASAS Y ACEITES 67 (1)

January-March 2016, e119

ISSN-L: 0017-3495

doi: http://dx.doi.org/10.3989/gya.0492151

\title{
Effect of the amount of chestnuts in the diet of Celta pigs on the fatty acid profile of dry-cured lacon
}

\author{
M.C. de Jesús ${ }^{1}$, R. Domínguez ${ }^{2}$, J. Cantalapiedra ${ }^{3}$, A. Iglesias ${ }^{1}$ and J.M. Lorenzo ${ }^{2, \bowtie}$ \\ ${ }^{1}$ Departamento de Anatomía y Producción Animal. Universidad de Santiago de Compostela, 27002, Lugo, Spain \\ ${ }^{2}$ Centro Tecnológico de la Carne de Galicia, Rúa Galicia No 4, Parque Tecnológico de Galicia, San Cibrao das Viñas, 32900 Ourense, Spain \\ ${ }^{3}$ Farm Counselling Services. Consellería do Medio Rural, Xunta de Galicia, 27004, Lugo, Spain \\ ${ }^{\square}$ Corresponding author: jmlorenzo@ceteca.net
}

Submitted: 14 April 2015; Accepted: 21 September 2015

SUMMARY: The effect of including chestnuts in the formulation of the feed $(0,15$ and $25 \%$ chestnut $)$ on the fatty acids of dry-cured lacon from Celta pigs was studied. The inclusion of chestnuts decreases the saturated fatty acid content (SFA) and the monounsaturated fatty acid content (MUFA). With regards to the polyunsaturated fatty acids (PUFA), the lacon from animals fed with chestnuts presented higher values of total PUFA, n6 PUFAs and $n 3$ PUFAs. This is related to the fact that chestnut diets had the highest amounts of essential fatty acids (C18:2n6 and $\mathrm{C} 18: 3 \mathrm{n} 3)$, therefore the lacon from chestnut-fed animals also presented higher amounts of these fatty acids. According to nutritional ratios, lacon obtained from chestnut-fed pigs was healthier than the one obtained from pigs fed on commercial feed. The main conclusion is that including chestnuts in the diet allows us to obtain healthier dry-cured meat products.

KEYWORDS: Celta pig breed; Chestnut; Diet; Dry-cured lacon; Fatty acid content

RESUMEN: Efecto de la cantidad de castañas en la dieta sobre el perfil de ácidos grasos del lacón curado de cerdos Celta. Se estudió el efecto de la inclusión de la castaña en la formulación del pienso ( 0,15 y $25 \%$ de castaña) sobre el perfil de ácidos grasos del lacón curado de cerdo Celta. La inclusión de castañas produjo una disminución del contenido de ácidos grasos saturados (SFA) y monoinsaturados (MUFA). Con respecto a los ácidos grasos poliinsaturados (PUFA) los lacones de animales alimentados por castaña presentaron valores más altos de PUFA totales, PUFA n6 y PUFA n3. Esto está relacionado con que las castañas tienen una mayor cantidad de ácidos grasos esenciales (C18:2n6 y C18:3n3), por tanto los lacones de cerdos alimentados con castaña también presentan mayores contenidos de estos ácidos grasos. De acuerdo con los índices nutricionales, los lacones obtenidos de cerdos alimentados con mayor proporción de castañas fueron más saludables. La inclusión de castañas en la dieta nos permite obtener productos cárnicos curados más saludables.

PALABRAS CLAVE: Castañas; Cerdo de raza Celta; Contenido en ácidos grasos; Dieta; Lacón curado

Citation/Cómo citar este artículo: De Jesús MC, Domínguez R, Cantalapiedra J, Iglesias A, Lorenzo JM. 2016. Effect of the amount of chestnuts in the diet of Celta pigs on the fatty acid profile of dry-cured lacon. Grasas Aceites 67 (1): e119. doi: http://dx.doi.org/10.3989/gya.0492151.

Copyright: (C) 2016 CSIC. This is an open-access article distributed under the terms of the Creative Commons Attribution-Non Commercial (by-nc) Spain 3.0 Licence. 


\section{INTRODUCTION}

The chestnut (Castanea sativa Mill.) is a Geographically Protected Identity (G.P.I.) (Official Journal of the European Communities, 2010) in the NW of Spain, the main production area. In order to increase the quality of meat and meat products, it might be beneficial to recover some of the more traditional ingredients used in pig feeding such as chestnuts. In Galicia, the extensive rearing of pigs, similar to montanera in Iberian pigs, is difficult due to the small size of the farms; thus, feeding pigs with these products in large scale production can only be carried out by the use of concentrated diets (Díaz et al., 2009).

Chestnuts are characterized by a high moisture content (over $50 \%$ ), high levels of starch $\left(57 \mathrm{~g} \cdot 100 \mathrm{~g}^{-1}\right.$ dry matter-d.m.), a low protein level $\left(5.8 \mathrm{~g} \cdot 100 \mathrm{~g}^{-1} \mathrm{~d} . \mathrm{m}\right.$.) and low fat content ( $3 \mathrm{~g} \cdot 100 \mathrm{~g}^{-1} \mathrm{~d} . \mathrm{m}$.) (PereiraLorenzo et al., 2006). These fruits also have a significant content of polyphenols, with gallic acid and ellagic acid being predominant among the hydrolysable and condensed tannins (Gonçalves et al., 2010). In this sense, Barreira et al. (2008) evaluated the in vitro antioxidant activities of the extracts from chestnut flower, leaf, skin and fruit and found that chestnut skins had antioxidant properties, particularly against lipid peroxidation. Knowledge of the effect of providing chestnuts in controlled rearing conditions is scarce (Bermúdez et al., 2012; CoutronGambotti et al., 1998; Lorenzo et al., 2013; Lorenzo et al., 2014; Pugliese et al., 2013).

The Celta pig breed was the typical pig breed raised on farms in Galicia (NW of Spain) until the beginning of the $20^{\text {th }}$ century. However, with the arrival of improved breeds and their crosses, Celta pig production was displaced so that the Celta pig is included in the Official Catalogue of Cattle Breeds of Spain as being in danger of extinction (Real Decreto 2129/2008). The Celta carcasses, which are often very fatty, are used in the production of dry-cured meat products, which have a high value on the market and great quality (Lorenzo et al., 2012). There is a growing demand for products derived from autochthonous breeds. This has permitted an increment in the census of the Celta pig, increasing from 623 animals in 2001 to 4882 at the end of 2012 (Carril et al., 2013).

Dry-cured lacon is a traditional cured meat product made in the NW of Spain from the foreleg of the pig, which is cut at the shoulder blade-humerus joint, following a very similar manufacturing process as the one used in the production of dry-cured ham (Purriños et al., 2011). In the Galicia region, this product has been awarded a Geographically Protected Identity (Official Journal of the European Communities, 2001).

At the present time, chestnuts are underutilized and this situation contrasts with the high current prices of commercial concentrates for animal feed.
The use of chestnuts in the fattening feed, in an extensive management system, would allow for a reduction in production costs and put quality products on the market, differentiated by a high added value and with healthier fat (Bermúdez et al., 2012). In this regard, the smaller sized chestnuts and the by-products of this industry (pieces of chestnuts and chestnut meal) can be used in the elaboration of concentrated diets for pigs. So, the aim of this work was to study the effect of the inclusion of chestnuts in the pigs' diet on the fatty acid profile of Celta dry-cured lacon.

\section{MATERIALS AND METHODS}

\subsection{Experimental design and animal management}

The experiment was conducted on 24 Celta pigs. Experimental farms were located in Lugo (Spain). The pigs were reared in an extensive system with a forest of $960 \mathrm{~m}^{2}\left(40 \mathrm{~m}^{2}\right.$ per animal) composed of Eucalyptus spp. and Castanea sativa trees. Camping tents for rest and a pool for swimming were available in the area. The animals were fed a standard piglet diet for 3 months and then they were randomly divided into three groups. The first group was fed with a commercial diet as control (C diet) and it was composed basically of cereals (barley, soy and wheat), the second group was fed a diet containing $15 \%$ dried chestnuts (CH15) and the third group was fed a diet containing $25 \%$ dried chestnuts (CH25). The chemical and fatty acid compositions of the diets are shown in Table 1. The feed composition was determined according to AOAC (2005) procedures. The animals were feed ad libitum and slaughtered by electrical stunning and exsanguinations at a commercial abattoir (Castro Riberas de Lea, Lugo, Spain) when they were 12 months old. The carcasses attained an average weight of $103.58 \pm 5.86,118.66 \pm 6.97$ and $105.50 \pm 8.12 \mathrm{~kg}$, $P<0.01$ for $\mathrm{C}, \mathrm{CH} 15$ and $\mathrm{CH} 25$ groups, respectively.

\subsection{Samples}

After the refrigeration period $\left(24 \mathrm{~h}\right.$ at $\left.4{ }^{\circ} \mathrm{C}\right)$, lacon pieces were extracted from the left side of the carcass. A total of 24 lacon pieces (8 if each group; 1 per animal) were used. The raw pieces were dry salted with an excess of coarse salt. A heap was formed consisting of alternating layers of lacon pieces and layers of salt. The pieces $(4.68 \pm 0.32$, $5.40 \pm 0.61$ and $4.65 \pm 0.87 \mathrm{~kg}, P<0.05$ for $\mathrm{C}, \mathrm{CH} 15$ and $\mathrm{CH} 25$ groups, respectively) were totally covered with salt and they remained in the heap for five days. The temperature of the salting room was in the range $2-5^{\circ} \mathrm{C}$ and $80-90 \%$ relative humidity. After the salting stage, the pieces were taken from the heap, brushed, washed to remove salt from the surface, and transferred to a post-salting chamber where they stayed for 14 days at $2-5{ }^{\circ} \mathrm{C}$ and $85 \%$ 
TABLE 1. Chemical composition and fatty acid profile of the concentrates

\begin{tabular}{|c|c|c|c|c|c|}
\hline & \multicolumn{3}{|c|}{ Diet } & \multirow[b]{2}{*}{ SEM } & \multirow[b]{2}{*}{ Sig. } \\
\hline & $\mathbf{C}$ & CH15 & CH25 & & \\
\hline \multicolumn{6}{|c|}{ Chemical composition (\%) } \\
\hline Moisture & $10.50 \pm 0.09^{\mathrm{a}}$ & $11.20 \pm 0.11^{\mathrm{b}}$ & $11.00 \pm 0.06^{\mathrm{b}}$ & 0.03 & $*$ \\
\hline Crude protein & $15.90 \pm 0.16^{\mathrm{c}}$ & $14.20 \pm 0.12^{\mathrm{b}}$ & $13.30 \pm 0.09^{\mathrm{a}}$ & 0.07 & $* * *$ \\
\hline Ether extract & $4.40 \pm 0.04^{\mathrm{c}}$ & $4.20 \pm 0.07^{\mathrm{b}}$ & $4.00 \pm 0.05^{\mathrm{a}}$ & 0.03 & $* * *$ \\
\hline Crude fiber & $4.20 \pm 0.02^{\mathrm{b}}$ & $4.20 \pm 0.01^{\mathrm{b}}$ & $4.10 \pm 0.01^{\mathrm{a}}$ & 0.01 & $*$ \\
\hline Ash & $4.40 \pm 0.04^{\mathrm{c}}$ & $4.10 \pm 0.02^{\mathrm{b}}$ & $3.90 \pm 0.02^{\mathrm{a}}$ & 0.01 & $* * *$ \\
\hline Starch & $48.30 \pm 0.07^{\mathrm{c}}$ & $44.80 \pm 0.09^{\mathrm{a}}$ & $45.30 \pm 0.12^{\mathrm{b}}$ & 0.06 & $* *$ \\
\hline \multicolumn{6}{|c|}{ Fatty acid profile (\%) } \\
\hline $\mathrm{C} 12: 0$ & $0.03 \pm 0.01$ & $0.03 \pm 0.01$ & $0.04 \pm 0.01$ & 0.01 & $* *$ \\
\hline $\mathrm{C} 14: 0$ & $0.89 \pm 0.01^{\mathrm{c}}$ & $0.82 \pm 0.01^{\mathrm{b}}$ & $0.75 \pm 0.01^{\mathrm{a}}$ & 0.01 & $* * *$ \\
\hline C14:1 & $0.07 \pm 0.01$ & $0.07 \pm 0.01$ & $0.06 \pm 0.01$ & 0.01 & ns \\
\hline $\mathrm{C} 15: 0$ & $0.12 \pm 0.01$ & $0.11 \pm 0.01$ & $0.11 \pm 0.01$ & 0.01 & ns \\
\hline $\mathrm{C} 16: 0$ & $19.38 \pm 0.02^{\mathrm{c}}$ & $18.65 \pm 0.03^{\mathrm{b}}$ & $18.13 \pm 0.02^{\mathrm{a}}$ & 0.02 & $* * *$ \\
\hline $\mathrm{C} 16: \ln 7$ & $1.44 \pm 0.01^{\mathrm{c}}$ & $1.35 \pm 0.01^{\mathrm{b}}$ & $1.25 \pm 0.01^{\mathrm{a}}$ & 0.01 & $* * *$ \\
\hline $\mathrm{C} 17: 0$ & $0.35 \pm 0.01^{\mathrm{c}}$ & $0.32 \pm 0.01^{\mathrm{b}}$ & $0.29 \pm 0.01^{\mathrm{a}}$ & 0.01 & $* * *$ \\
\hline $\mathrm{C} 17: \ln 7$ & $0.19 \pm 0.01$ & $0.18 \pm 0.01$ & $0.17 \pm 0.01$ & 0.01 & ns \\
\hline C18:0 & $8.42 \pm 0.02^{\mathrm{c}}$ & $7.28 \pm 0.01^{\mathrm{b}}$ & $6.41 \pm 0.01^{\mathrm{a}}$ & 0.01 & $* * *$ \\
\hline $\mathrm{C} 18: \ln 9$ & $29.85 \pm 0.04^{\mathrm{a}}$ & $30.48 \pm 0.03^{\mathrm{b}}$ & $30.72 \pm 0.04^{\mathrm{c}}$ & 0.03 & $* * *$ \\
\hline $\mathrm{C} 18: 2 \mathrm{n} 6$ & $32.27 \pm 0.04^{\mathrm{a}}$ & $33.53 \pm 0.01^{\mathrm{b}}$ & $34.67 \pm 0.02^{\mathrm{c}}$ & 0.02 & $* * *$ \\
\hline $\mathrm{C} 20: 0$ & $0.26 \pm 0.01$ & $0.27 \pm 0.01$ & $0.27 \pm 0.01$ & 0.01 & ns \\
\hline $\mathrm{C} 18: 3 \mathrm{n} 3$ & $2.14 \pm 0.01^{\mathrm{a}}$ & $2.59 \pm 0.01^{\mathrm{b}}$ & $2.97 \pm 0.01^{\mathrm{c}}$ & 0.01 & $* * *$ \\
\hline $\mathrm{C} 20: 3 \mathrm{n} 3$ & $0.03 \pm 0.01$ & $0.03 \pm 0.01$ & $0.03 \pm 0.01$ & 0.01 & ns \\
\hline $\mathrm{C} 20: 4 \mathrm{n} 6$ & $0.10 \pm 0.02$ & $0.08 \pm 0.01$ & $0.09 \pm 0.03$ & 0.02 & ns \\
\hline $\mathrm{C} 20: 5 \mathrm{n} 3$ & $0.13 \pm 0.01$ & $0.13 \pm 0.01$ & $0.13 \pm 0.01$ & 0.01 & ns \\
\hline $\mathrm{C} 24: \ln 9$ & $0.03 \pm 0.01$ & $0.03 \pm 0.01$ & $0.03 \pm 0.01$ & 0.01 & ns \\
\hline $\mathrm{C} 22: 5 \mathrm{n} 3$ & $0.03 \pm 0.01$ & $0.02 \pm 0.01$ & $0.02 \pm 0.01$ & 0.01 & $\mathrm{~ns}$ \\
\hline $\mathrm{C} 22: 6 \mathrm{n} 3$ & $0.02 \pm 0.01$ & $0.02 \pm 0.01$ & $0.02 \pm 0.01$ & 0.01 & ns \\
\hline SFA & $29.68 \pm 0.03^{\mathrm{c}}$ & $27.72 \pm 0.05^{\mathrm{b}}$ & $26.27 \pm 0.03^{\mathrm{a}}$ & 0.02 & $* * *$ \\
\hline MUFA & $35.20 \pm 0.05$ & $35.49 \pm 0.04$ & $35.44 \pm 0.06$ & 0.04 & ns \\
\hline PUFA & $35.09 \pm 0.06^{\mathrm{a}}$ & $36.76 \pm 0.03^{b}$ & $38.25 \pm 0.07^{\mathrm{c}}$ & 0.03 & $* * *$ \\
\hline
\end{tabular}

C: concentrate feed (control); $\mathrm{CH} 15$ : concentrate feed containing 15\% dried chestnuts; $\mathrm{CH} 25$ : concentrate feed containing $25 \%$ dried chestnuts; SEM=standard error of the mean; ${ }^{\mathrm{a}-\mathrm{b}}$ Means in the same row with different letters differ significantly $(P<0.05$; Duncan test $)$; Significance: $* * *(P<0.001)$, $* *(P<0.01), *(P<0.05)$, n.s (not significant).

relative humidity. After the post-salting stage the pieces were transferred to a room at $12{ }^{\circ} \mathrm{C}$ and $60 \%$ relative humidity where drying-ripening took place for 30 days. After this period, the samples were skinned, deboned, and the infraspinatus, triceps brachiilateralis and deltoideus muscles were extracted. The samples were minced, vacuum-packed and stored at $-30^{\circ} \mathrm{C}$ for no longer than four weeks until analysis.

\subsection{Analysis of fatty acid methyl esters}

Lipids were extracted from the muscles following the Bligh and Dyer (1959) method. Methyl esters of the samples were produced according to the method of Morrison and Smith (1964). Fifty milligrams of the extracted lipids were esterified with $4 \mathrm{~mL}$ of borontrifluoride $(13 \%)$ in methanol. The sample was heated at $100{ }^{\circ} \mathrm{C}$ during 30 minutes and fatty acid methyl esters (FAMEs) were extracted with $2 \mathrm{~mL}$ of hexane and stored at $-80^{\circ} \mathrm{C}$ until chromatographic analysis.

Separation and quantification of FAMEs was carried out using a gas chromatograph, Carlo Erba Instruments MFC 500 auto/HRGC/MS (Milan, Italy) equipped with a flame ionization detector and using a Supelco DB-23 fused silica capillary column (30 m, $0.32 \mathrm{~mm}$ i.d., $0.25 \mu \mathrm{m}$ film thickness, Supelco Inc., Bellafonte, PA, USA). Chromatographic conditions were as follows: initial oven temperature $170^{\circ} \mathrm{C}$ 
(held for $2 \mathrm{~min}$ ), first ramp at $3.5^{\circ} \mathrm{C} \cdot \mathrm{min}^{-1}$ to $210^{\circ} \mathrm{C}$ and second ramp at $2.5^{\circ} \mathrm{C} \cdot \mathrm{min}^{-1}$ to $250^{\circ} \mathrm{C}$ (held for $5 \mathrm{~min})$. The injector and detector were maintained at $250^{\circ} \mathrm{C}$. Helium was used as carrier gas at a constant flow-rate of $2.0 \mathrm{~mL} \cdot \mathrm{min}^{-1}$. The split ratio was 1:50 and $1 \mu \mathrm{L}$ of solution was injected. Nonadecanoic acid methyl ester $(\mathrm{C} 19: 0 \mathrm{ME})$ at $0.3 \mathrm{mg} \cdot \mathrm{mL}^{-1}$ was used as internal standard and added to the samples prior to fat extraction and methylation. Individual FAMEs were identified by comparing their retention times with those of authentic standards. Data regarding FAME composition were expressed as $\mathrm{g} \cdot 100 \mathrm{~g}^{-1}$ of total identified FAMEs. The proportion of saturated (SFA), monounsaturated (MUFA) and polyunsaturated (PUFA) fatty acid contents, PUFA/SFA, n6/n3, and the hypocholesterolemic/ Hypercholesterolemic ratio were calculated.

\subsection{Statistical analysis}

All statistical analyses were performed using IBM SPSS Statistics 19 software (IBM, Chicago, IL, USA). After verification of the normal distribution and constant variance of data, significant differences were determined using one-way analysis of variance (ANOVA) to analyze the effect of the inclusion of chestnuts in the diet on the fatty acid profile of Celta dry-cured lacón. The least squares means (LSM) were separated using Duncan's test. All statistical tests of LSM were performed for a significance level of $P<0.05$. Correlations between variables $(P<0.05)$ were determined by a correlation analysis using Pearson's linear correlation coefficient.

To evaluate the relation between variables a factorial analysis of the fatty acids with significant differences $(P<0.05)$ among the three groups was carried out. A principal component analysis (PCA) was used as extraction method and was performed on the correlation matrix. In order to verify the capacity of the fatty acid analysis as a tool for diet feed type discrimination in dry-cured lacon a stepwise discriminate analysis was done. An "a priori" equal probability for a sample to be in one group independently of the group size was considered. The criterion for the selection of variables was Wilk's lambda ( $F$ to enter and out value of 3.84 and 2.71 , respectively).

\section{RESULTS AND DISCUSSION}

Table 2 shows the fatty acid composition (expressed as $\mathrm{g} / 100 \mathrm{~g}$ of total fatty acids) of the intramuscular fat of lacon samples from pigs fed the $\mathrm{C}, \mathrm{CH} 15$ and $\mathrm{CH} 25$ diets. Intramuscular fat did not show significant differences $(P<0.05)$ among groups $(19.80 \pm 0.74$ vs. $21.26 \pm 0.68 v s .18 .66 \pm 0.80 \mathrm{~g} \cdot 100 \mathrm{~g}^{-1}$ of dry matter for $\mathrm{C}, \mathrm{CH} 15$ and $\mathrm{CH} 25$ feed, respectively) (data not shown). Significant $(P<0.05)$ differences among treatments were observed regarding saturated fatty acid (SFA), monounsaturated fatty acid (MUFA) and polyunsaturated fatty acid (PUFA). Celta lacon (from $\mathrm{CH} 15$ and $\mathrm{CH} 25$ diets) presented significantly $(P<0.001)$ lower percentages of SFA and significantly $(P<0.001)$ higher proportions of PUFA than those from the control fed animals. This outcome is in agreement with those reported by Bermúdez et al. (2012) who found lower SFA contents in Celta hams from pigs fed with a diet of chestnuts only $(5 \mathrm{~kg} /$ animal a day) in the three months prior to slaughter. A similar result was observed by Pugliese et al. (2013) in fresh back fat from Cinta Senese pigs fed with chestnuts during the fattening period and by Domínguez et al. (2015) who also found the lowest SFA values in longissimus dorsi and psoas major fat in Celta pigs fed only with chestnuts during the finishing diet.

As mentioned above, lacons from the $\mathrm{CH} 15$ and CH25 diets displayed lower contents of SFA than lacón from the control group (31.14 vs. $30.55 v s$. $36.60 \mathrm{~g} \cdot 100 \mathrm{~g}^{-1}, P<0.001$, respectively). Within SFA, palmitic acid (C16:0) was the most abundant fatty acid (representing about $65 \%$ of total SFA) with values of $24.07,20.43$ and $20.60 \mathrm{~g} \cdot 100 \mathrm{~g}^{-1}$ for C, $\mathrm{CH} 15$ and $\mathrm{CH} 25$ treatments, respectively. These findings are in agreement with those previously reported by Cobos et al. (2008) in lacón and Bermúdez et al. (2012) in ham. It was found from the Pearson correlation test that SFA content was positively correlated with $\mathrm{C} 16: 0(\mathrm{r}=0.973, P<0.01)$. The lacon from the $\mathrm{C}$ group also presented higher $(P<0.05)$ amounts of stearic acid $(\mathrm{C} 18: 0)$ than the lacon from chestnuts groups $(9.35 \mathrm{vs} .7 .46 \mathrm{vs}$. $7.95 \mathrm{~g} \cdot 100 \mathrm{~g}^{-1}$ in lacon for $\mathrm{C}, \mathrm{CH} 15$ and $\mathrm{CH} 25$ groups, respectively). The higher amounts of SFA, C16:0 and C18:0 in lacon from the control group is linked to the higher amounts of C16:0 (19.36 vs. 18.65 vs. $18.13 \mathrm{~g} \cdot 100 \mathrm{~g}^{-1}$ for $\mathrm{C}, \mathrm{CH} 15$ and $\mathrm{CH} 25$ feed, respectively) and $\mathrm{C} 18: 0$ (8.42 vs. $7.28 \mathrm{vs}$. $6.41 \mathrm{~g} / 100 \mathrm{~g}$ for $\mathrm{C}, \mathrm{CH} 15$ and $\mathrm{CH} 25$ feed, respectively) in the control diet. The de novo synthesis of the five main non-essential fatty acids (C14:0, C16:0, $\mathrm{C} 16: 1 \mathrm{n} 7, \mathrm{C} 18: 0$ and $\mathrm{C} 18: 1 \mathrm{n} 9)$ represented $92 \%$ of the total deposited fatty acids (Kloareg et al., 2005). It is well known that the carbohydrates serve as substrate in the synthesis of fat, producing C16:0. This fatty acid can then be elongated by the action of the elongase enzymes, resulting in an increase in the amount of C18:0. In the present study the control diet presented higher contents of starch than the chestnut diet (48.30 vs. 44.80 vs. $45.30 \mathrm{~g} \cdot 100 \mathrm{~g}^{-1}$ for C, CH15 and CH25 diets, respectively; see Table 1). Therefore, the highest content of C16:0 and C18:0 in lacons from the $\mathrm{C}$ group could be linked to the fact that de novo synthesis was favored in pigs fed with the control diet. The SFAs, specifically myristic acid $(\mathrm{C} 14: 0)$ and $\mathrm{C} 16: 0$ are typically among the most concentrated FAs in meat and they have been associated with cardiovascular disease (CVD), 
Effect of the amount of chestnuts in the diet of Celta pigs on the fatty acid profile of dry-cured lacon $\bullet 5$

TABLE 2. Effect of diet on fatty acid contents (meantstandard error) of intramuscular fat of dry-cured "lacon" from Celta pig breed

\begin{tabular}{|c|c|c|c|c|c|}
\hline \multirow[b]{2}{*}{ Fatty acid } & \multicolumn{3}{|c|}{ Diet } & \multirow[b]{2}{*}{ SEM } & \multirow[b]{2}{*}{ Sig. } \\
\hline & $\mathbf{C}$ & CH15 & $\mathrm{CH} 25$ & & \\
\hline C10:0 & $0.15 \pm 0.04$ & $0.18 \pm 0.08$ & $0.14 \pm 0.06$ & 0.01 & n.s. \\
\hline $\mathrm{C} 12: 0$ & $0.18 \pm 0.21$ & $0.06 \pm 0.07$ & $0.07 \pm 0.06$ & 0.07 & n.s. \\
\hline $\mathrm{C} 14: 0$ & $1.62 \pm 0.75$ & $1.73 \pm 0.39$ & $1.53 \pm 0.21$ & 0.10 & n.s. \\
\hline $\mathrm{C} 14: 1$ & $0.05 \pm 0.02$ & $0.05 \pm 0.02$ & $0.05 \pm 0.01$ & 0.01 & n.s. \\
\hline $\mathrm{C} 15: 0$ & $0.06 \pm 0.02^{\mathrm{a}}$ & $0.12 \pm 0.05^{\mathrm{a}}$ & $0.34 \pm 0.16^{\mathrm{b}}$ & 0.03 & $* * *$ \\
\hline $\mathrm{C} 16: 0$ & $24.07 \pm 2.13^{\mathrm{b}}$ & $20.43 \pm 1.82^{\mathrm{a}}$ & $20.60 \pm 2.12^{\mathrm{a}}$ & 0.54 & $* *$ \\
\hline $\mathrm{C} 16: \ln 7$ & $4.24 \pm 0.43^{\mathrm{b}}$ & $2.75 \pm 0.39^{\mathrm{a}}$ & $2.86 \pm 0.51^{\mathrm{a}}$ & 0.17 & $* * *$ \\
\hline $\mathrm{C} 17: 0$ & $0.20 \pm 0.03$ & $0.24 \pm 0.06$ & $0.20 \pm 0.02$ & 0.01 & n.s. \\
\hline $\mathrm{C} 17: \ln 7$ & $0.23 \pm 0.02^{\mathrm{a}}$ & $0.38 \pm 0.03^{\mathrm{c}}$ & $0.33 \pm 0.02^{\mathrm{b}}$ & 0.01 & $* * *$ \\
\hline $\mathrm{C} 18: 0$ & $9.35 \pm 0.74^{\mathrm{b}}$ & $7.46 \pm 0.50^{\mathrm{a}}$ & $7.95 \pm 2.19^{\mathrm{a}}$ & 0.31 & $*$ \\
\hline C18:1n9 & $43.77 \pm 1.19$ & $42.08 \pm 2.88$ & $41.33 \pm 2.96$ & 0.54 & n.s. \\
\hline $\mathrm{C} 18: 2 \mathrm{n} 6$ & $14.40 \pm 1.42^{\mathrm{a}}$ & $19.31 \pm 1.11^{\mathrm{b}}$ & $18.29 \pm 1.06^{\mathrm{b}}$ & 0.52 & $* * *$ \\
\hline $\mathrm{C} 20: 0$ & $0.66 \pm 0.23^{\mathrm{a}}$ & $0.86 \pm 0.06^{\mathrm{b}}$ & $0.95 \pm 0.17^{\mathrm{b}}$ & 0.04 & $* *$ \\
\hline $\mathrm{C} 20: \ln 9$ & $0.49 \pm 0.10$ & $0.47 \pm 0.12$ & $0.50 \pm 0.10$ & 0.02 & n.s. \\
\hline $\mathrm{C} 18: 3 \mathrm{n} 3$ & $0.81 \pm 0.18^{\mathrm{a}}$ & $1.53 \pm 0.13^{\mathrm{c}}$ & $1.12 \pm 0.19^{\mathrm{b}}$ & 0.07 & $* * *$ \\
\hline $\mathrm{C} 20: 2 \mathrm{n} 6$ & $0.23 \pm 0.04^{\mathrm{c}}$ & $0.14 \pm 0.01^{\mathrm{b}}$ & $0.06 \pm 0.02^{\mathrm{a}}$ & 0.01 & $* * *$ \\
\hline $\mathrm{C} 20: 3 \mathrm{n} 3$ & $0.16 \pm 0.05^{\mathrm{a}}$ & $0.33 \pm 0.16^{\mathrm{b}}$ & $0.32 \pm 0.07^{\mathrm{b}}$ & 0.03 & $*$ \\
\hline $\mathrm{C} 20: 4 \mathrm{n} 6$ & $0.63 \pm 0.13$ & $0.74 \pm 0.25$ & $0.61 \pm 0.19$ & 0.04 & n.s. \\
\hline $\mathrm{C} 20: 5 \mathrm{n} 3$ & $0.35 \pm 0.03^{\mathrm{a}}$ & $1.42 \pm 0.43^{\mathrm{b}}$ & $2.81 \pm 0.99^{\mathrm{c}}$ & 0.24 & $* * *$ \\
\hline $\mathrm{C} 22: 0$ & $0.12 \pm 0.03$ & $0.18 \pm 0.01$ & $0.18 \pm 0.09$ & 0.01 & n.s. \\
\hline $\mathrm{C} 22: 4 \mathrm{n} 3$ & $0.17 \pm 0.15$ & $0.17 \pm 0.07$ & $0.19 \pm 0.09$ & 0.02 & n.s. \\
\hline $\mathrm{C} 22: 5 \mathrm{n} 3$ & $0.11 \pm 0.03^{\mathrm{a}}$ & $0.25 \pm 0.07^{\mathrm{b}}$ & $0.32 \pm 0.19^{\mathrm{b}}$ & 0.03 & $*$ \\
\hline $\mathrm{C} 22: 6 \mathrm{n} 3$ & $0.14 \pm 0.07^{\mathrm{a}}$ & $0.29 \pm 0.10^{\mathrm{b}}$ & $0.35 \pm 0.10^{\mathrm{b}}$ & 0.03 & $* *$ \\
\hline $\mathrm{C} 24: \ln 9$ & $0.10 \pm 0.03$ & $0.17 \pm 0.06$ & $0.14 \pm 0.04$ & 0.01 & n.s. \\
\hline SFA & $36.60 \pm 1.69^{\mathrm{b}}$ & $31.14 \pm 2.99^{\mathrm{a}}$ & $30.55 \pm 2.31^{\mathrm{a}}$ & 0.77 & $* * *$ \\
\hline MUFA & $48.85 \pm 1.51^{\mathrm{b}}$ & $45.58 \pm 2.44^{\mathrm{a}}$ & $45.21 \pm 2.92^{\mathrm{a}}$ & 0.58 & $*$ \\
\hline PUFA & $16.84 \pm 1.51^{\mathrm{a}}$ & $24.24 \pm 1.57^{\mathrm{b}}$ & $24.44 \pm 2.32^{\mathrm{b}}$ & 0.84 & $* * *$ \\
\hline PUFA/SFA & $0.46 \pm 0.04^{\mathrm{a}}$ & $0.76 \pm 0.08^{b}$ & $0.80 \pm 0.10^{\mathrm{b}}$ & 0.04 & $* * *$ \\
\hline$\Sigma \mathrm{n} 3$ & $1.05 \pm 0.21^{\mathrm{a}}$ & $2.11 \pm 0.32^{\mathrm{c}}$ & $1.79 \pm 0.30^{\mathrm{b}}$ & 0.11 & $* * *$ \\
\hline$\Sigma \mathrm{n} 6$ & $15.22 \pm 1.52^{\mathrm{a}}$ & $20.39 \pm 1.24^{\mathrm{b}}$ & $19.28 \pm 1.10^{\mathrm{b}}$ & 0.55 & $* * *$ \\
\hline $\mathrm{n} 6 / \mathrm{n} 3$ & $13.25 \pm 1.40^{\mathrm{b}}$ & $9.89 \pm 1.26^{\mathrm{a}}$ & $10.43 \pm 0.99^{\mathrm{a}}$ & 0.40 & $* * *$ \\
\hline $\mathrm{h} / \mathrm{H}$ & $2.24 \pm 0.48^{\mathrm{a}}$ & $3.00 \pm 0.47^{\mathrm{b}}$ & $2.95 \pm 0.41^{b}$ & 0.12 & $* *$ \\
\hline Nutritive value & $2.23 \pm 0.22$ & $2.45 \pm 0.37$ & $2.38 \pm 0.32$ & 0.07 & n.s. \\
\hline
\end{tabular}

C: concentrate feed (control); CH15: concentrate feed containing 15\% dried chestnuts; $\mathrm{CH} 25$ : concentrate feed containing $25 \%$ dried chestnuts; SEM $=$ standard error of the mean; ${ }^{\mathrm{a}-\mathrm{b}}$ Means in the same row with different letters differ significantly $(P<0.05$; Duncan test $)$; Significance: *** $(P<0.001)$, $* *(P<0.01), *(P<0.05)$, n.s (not significant); PUFA $=\Sigma(\mathrm{C} 18: 2 \mathrm{n} 6+\mathrm{C} 18: 3 \mathrm{n} 3+\mathrm{C} 20: 3 \mathrm{n} 3+\mathrm{C} 20: 4 \mathrm{n} 6+$ $\mathrm{C} 20: 5 \mathrm{n} 3+\mathrm{C} 22: 4 \mathrm{n} 3+\mathrm{C} 22: 6 \mathrm{n} 3) ; \mathrm{MUFA}=\Sigma(\mathrm{C} 14: 1+\mathrm{C} 16: 1 \mathrm{n} 7+\mathrm{C} 17: 1+\mathrm{C} 18: 1 \mathrm{n} 9+\mathrm{C} 24: 1 \mathrm{n} 9) ; \mathrm{SFA}=\Sigma(\mathrm{C} 12: 0+$ $\mathrm{C} 14: 0+\mathrm{C} 15: 0+\mathrm{C} 16: 0+\mathrm{C} 17: 0+\mathrm{C} 18: 0+\mathrm{C} 20: 0+\mathrm{C} 22: 0) ; \Sigma \mathrm{n}-6=\Sigma(\mathrm{C} 18: 2 \mathrm{n} 6+\mathrm{C} 20: 4 \mathrm{n} 6) ; \Sigma \mathrm{n}-3=\Sigma(\mathrm{C} 18: 3 \mathrm{n} 3+$ $\mathrm{C} 20: 3 \mathrm{n} 3+\mathrm{C} 20: 5 \mathrm{n} 3+\mathrm{C} 22: 4 \mathrm{n} 3+\mathrm{C} 22: 6 \mathrm{n} 3) ; \mathrm{h} / \mathrm{H}$ : the hypocholesterolemic/Hypercholesterolemic ratio $=[$ (sum of $\mathrm{C} 18: 1 \mathrm{n} 9, \mathrm{C} 18: 2 \mathrm{n} 6, \mathrm{C} 18: 3 \mathrm{n} 3, \mathrm{C} 20: 2 \mathrm{n} 6, \mathrm{C} 20: 3 \mathrm{n} 3, \mathrm{C} 20: 4 \mathrm{n} 6, \mathrm{C} 20: 5 \mathrm{n} 3, \mathrm{C} 22: 4 \mathrm{n} 3$, $\mathrm{C} 22: 5 \mathrm{n} 3$ and $\mathrm{C} 22: 6 \mathrm{n} 3) /($ sum of $\mathrm{C} 14: 0$ and C16:0)] (Fernández et al., 2007); Nutritive value: $(\mathrm{C} 18: 0+\mathrm{C} 18: \ln 9) /(\mathrm{C} 16: 0)$.

colorectal cancer and type 2 diabetes (Micha and Mozaffarian, 2010). This is an interesting finding since nutritional guidelines recommend a lower intake of SFA and trans fatty acids (TFA) as well as a higher PUFA intake (especially of the $\mathrm{n} 3 \mathrm{fam}-$ ily of PUFA to comply with an appropriate n6/n3 balance) in order to prevent cardiovascular diseases (Sierra et al., 2008). 
On the other hand, the intramuscular fat of the lacon samples from pigs fed with chestnuts (CH15 and CH25 treatments) showed a significantly $(P<0.05)$ lower content of MUFA (45.58 and $45.21 \mathrm{~g} \cdot 100 \mathrm{~g}^{-1}$ from $\mathrm{CH} 15$ and $\mathrm{CH} 25$ groups, respectively) than the lacon from animals fed the control diet (48.85 g·100 g $\left.{ }^{-1}\right)$. In contrast, Bermúdez et al. (2012) in ham and Domínguez et al. (2015) in fresh meat found that the inclusion of chestnuts in the finishing diet increased MUFA amounts. The higher amount of MUFA in lacon from pigs fed the control diet is directly related to the higher content $(P<0.001)$ of palmitoleic acid (C16:1n 7; 4.24 vs. 2.75 vs. $2.86 \mathrm{~g} \cdot 100 \mathrm{~g}^{-1}$ for $\mathrm{C}, \mathrm{CH} 15$ and $\mathrm{CH} 25$ groups, respectively). It has been suggested that fat deposition in different depots might be regulated by different mechanisms (Gondret et al., 2008) and stearoyl-CoA desaturase plays a key role in this process (Doran et al., 2006). As mentioned above, the amount of $\mathrm{C} 16: \ln 7$ depends on the de novo synthesis. Therefore, the higher contents of carbohydrates in the control diet results in the lacon from animals fed with this diet having the highest amounts of $\mathrm{C} 16: 1 \mathrm{n} 7$. On the contrary, lacon from chestnut-fed pigs presented higher values of $\mathrm{C} 17: \ln 7$ than those of pigs fed with concentrate. This result is in agreement with those previously observed by Bermúdez et al. (2012) in Celta pigs fed a diet based on chestnuts. The odd-chain fatty acid $(\mathrm{C} 17: \ln 7)$ is increased due to the endogenous synthesis coming from the propionic acid derived from the fermentation of dietary fiber (Díaz et al., 2009). However, in this study there were no differences in the crude fiber amounts among diets.

Statistical analysis showed that the inclusion of chestnuts in the diet increased $(P<0.001)$ PUFA contents (16.84 vs. 24.24 vs. $24.44 \mathrm{~g} \cdot 100 \mathrm{~g}^{-1}$ from lacon for the $\mathrm{C}, \mathrm{CH} 15$ and $\mathrm{CH} 25$ groups, respectively). An increase in omega 6 (15.22 vs. $20.39 v s$. $19.28 \mathrm{~g} \cdot 100 \mathrm{~g}^{-1}$ from lacon for the $\mathrm{C}, \mathrm{CH} 15$ and CH25 groups, respectively; $P<0.001)$ and omega 3 (1.05 vs. 2.11 vs. $1.79 \mathrm{~g} \cdot 100 \mathrm{~g}^{-1}$ from lacon for the $\mathrm{C}, \mathrm{CH} 15$ and $\mathrm{CH} 25$ groups, respectively; $P<0.001$ ) The amount of PUFAs was appreciated as being increased due to chestnuts in the diet. This fact agrees with the results described by Coutron-Gambotti et al. (1998), who reported higher contents of PUFA in the biceps femoris muscle in pigs fed with chestnuts. These authors explained the higher PUFA contents in the muscles of pigs fed with chestnuts on the basis of differences in the mechanisms of the de novo synthesis of fatty acids from carbohydrates or of the desaturation and elongation of both endogenous and dietary fatty acids. In contrast, Temperan et al. (2014) did not find differences in PUFA contents between pigs fed with chestnuts and commercial feed while Bermúdez et al. (2012) and Domínguez et al. (2015) observed that the inclusion of chestnuts in the finishing diet decreased PUFA contents. Within omega 6 PUFAs only linoleic acid (C18:2n6) presented significant differences among groups. Lacon from the $\mathrm{CH} 15$ and $\mathrm{CH} 25$ groups showed higher $(P<0.001)$ amounts of $\mathrm{C} 18: 2 \mathrm{n} 6 \quad(19.31$ and $18.29 \mathrm{~g} \cdot 100 \mathrm{~g}^{-1}$, respectively) than lacon from the C group $\left(14.40 \mathrm{~g} \cdot 100 \mathrm{~g}^{-1}\right)$. These findings agree with the results obtained by Pugliese et al. (2013). In contrast, Bermúdez et al. (2012) and Domínguez et al. (2015) found a decrease in this fatty acid as the amount of the chestnuts in the diet increased. Regarding omega 3 fatty acids (C18:3n $3, \mathrm{C} 20: 3 \mathrm{n} 3$, $\mathrm{C} 20: 5 \mathrm{n} 3, \mathrm{C} 22: 5 \mathrm{n} 3$ and $\mathrm{C} 22: 6 \mathrm{n} 3)$, five out of six omega 3 PUFAs were affected by diet. In all cases, the increase in chestnuts in the diet also increases the amount of $n 3$ PUFAs. $\alpha$-Linolenic acid (C18:3n3) was the major $\mathrm{n} 3$ fatty acid. The Lacon from the $\mathrm{CH} 15$ group presented the highest $(P<0.001)$ amounts of $\mathrm{C} 18: 3 \mathrm{n} 3\left(1.53 \mathrm{~g} \cdot 100 \mathrm{~g}^{-1}\right)$, followed by the lacon from the $\mathrm{CH} 25$ group $\left(1.12 \mathrm{~g} \cdot 100 \mathrm{~g}^{-1}\right)$ and by the lacon from the $C$ group $\left(0.81 \mathrm{~g} \cdot 100 \mathrm{~g}^{-1}\right)$. These results agree with those reported by Bermúdez et al. (2012) in ham and Domínguez et al. (2015) in subcutaneous fat, who found an increase in C18:3n 3 when the chestnut was included in the diet. However, Domínguez et al. (2015) and Temperan et al. (2014) did not find differences in the amount of this fatty acid in intramuscular fat between chestnut and control diets. The $\mathrm{C} 18: 2 \mathrm{n} 6$ and $\mathrm{C} 18: 3 \mathrm{n} 3$ contents in the porcine tissues are directly related to the dietary contents of these two fatty acids because they cannot be synthesised in the tissues (Mitchaothai et al., 2007; Teye et al., 2006). Therefore, the higher contents of C18:2n6 and C18:3n 3 in the lacon from animals fed with chestnut diets was due to the higher content of these fatty acids in the $\mathrm{CH} 15$ and $\mathrm{CH} 25$ diets. As mentioned above, also eicosatrienoic acid (C20:3n3), eicosapentaenoic acid (C20:5n3; EPA), docosapentaenoic acid (C22:5n3; DPA) and docosahexaenoic acid (C22:6n3; DHA) amounts increased as the chestnut was included in the diet. The $\mathrm{C} 18: 3 \mathrm{n} 3 \mathrm{acid}$ is the precursor of the synthesis of the other omega 3 PUFAs, although they can be incorporated from the diet. In the present research, the diets presented similar values of C20:3n3, EPA, DPA and DHA, therefore, the highest content of these fatty acids in the lacon from $\mathrm{CH} 15$ and $\mathrm{CH} 25$ is related to their greater synthesis from $\mathrm{C} 18: 3 \mathrm{n} 3$.

The higher conversion of the essential fatty acids into n-3 long-chain PUFAs than into n-6 PUFAs could be explained because they share the enzymes involved in their metabolism. These findings agree with the results obtained by Domínguez et al. (2015), Raes et al. (2004) and Rey et al. (2004), who found that there is competition between the C18:2n6 and C18:3n 3 for incorporation into the lipid molecules as well as for the enzymes involved in the processes of elongation and desaturation. Moreover, in the present study there was a preferential elongation and desaturation of C18:3n3. Domínguez et al. (2015) also found a preferential incorporation of omega 
3 PUFAs compared to omega 6 PUFAs into animal tissues. The high PUFA and lower SFA amounts observed in the lacon from chestnut groups indicate its suitability for healthier diets, due to human diets rich in PUFA, particularly n3 PUFA such as C18:3n3, EPA, DPA and DHA, which have been reported to have positive effects on health (LopezHuertas, 2010).

In order to establish which group presented the healthiest fat, the PUFA/SFA ratio (P/S) and the PUFA n6/n3 ratio were calculated. In relation to $\mathrm{P} / \mathrm{S}$, a value above 0.4 is recommended for healthy foods and diets (UK Department of Health, 1994) although, the high proportion of PUFA in and of itself is not necessarily healthy if it is not balanced in relation to the $n 6 / n 3$ ratio. Simopoulos (2004) reported that high n6/n3 PUFA ratios promote several kinds of pathogenesis, including CVD, cancer and inflammatory and autoimmune diseases. In our work, the lacon from chestnut-fed animals had higher values $(P<0.001)$ of $\mathrm{P} / \mathrm{S}$ ratio $(0.76$ and 0.80 from $\mathrm{CH} 15$ and $\mathrm{CH} 25$, respectively) than animals from the $\mathrm{C}$ group (0.46). In addition, the lacon from chestnut-fed animals also presented the best n6/n3 ratios (9.89 and 10.43 from $\mathrm{CH} 15$ and $\mathrm{CH} 25$, respectively) in comparison with those observed in the $\mathrm{C}$ group (13.25). Although $\mathrm{CH} 15$ and $\mathrm{CH} 25$ lacón showed lower values of $n 6 / n 3$, ratios obtained in the three groups were higher than the maximum levels recommended by different authors and institutions, such as the British Nutrition Foundation (1992) (n6/ n3 ratio=6) or Simopoulos (2004) (n6/n3 ratio=4).

The ratio of hypocholesterolaemic/Hypercholesterolaemic $(\mathrm{h} / \mathrm{H})$ fatty acids is also an effective parameter for measuring the healthiness of a fat, based on the functional effects of fatty acids on cholesterol metabolism (Santos-Silva et al., 2002). The percentage of fatty acids considered as hypocholesterolaemic was higher in the CH15 $\left(66.26 \mathrm{~g} \cdot 100 \mathrm{~g}^{-1}\right.$ of fat) and $\mathrm{CH} 25\left(65.40 \mathrm{~g} \cdot 100 \mathrm{~g}^{-1}\right.$ of fat) groups than in the $C$ group $\left(60.77 \mathrm{~g} \cdot 100 \mathrm{~g}^{-1}\right.$ of fat), while the amount of hypercholesterolaemic fatty acids showed the opposite behavior $\left(25.69,22.16\right.$ and $22.13 \mathrm{~g} \cdot 100 \mathrm{~g}^{-1}$ of fat from $\mathrm{C}, \mathrm{CH} 15$ and $\mathrm{CH} 25$ groups, respectively) (data not shown). Consequently, the $\mathrm{h} / \mathrm{H}$ ratio was significantly higher $(P<0.01)$ in chestnut-fed lacon (3.00 and 2.95 from the $\mathrm{CH} 15$ and $\mathrm{CH} 25$ group, respectively) than in the control lacon (2.24).

Finally, the nutritive value $(\mathrm{C} 18: 0+\mathrm{C} 18: \ln 9) /$ C16:0), which indicates the healthiness of the diet with regard to its lipid content, represents an important part of the fatty acids as a whole. Within the components of this ratio, C16:0 leads to increased blood cholesterol, while C18:0 does not affect cholesterol levels and $\mathrm{C} 18: \ln 9$ helps to decrease them. In the present study, a statistical analysis did not show differences among the three groups. Although there were no significant differences, slightly higher values were obtained for lacon from chestnut-fed pigs (2.45 and 2.38 from $\mathrm{CH} 15$ and $\mathrm{CH} 25$ groups, respectively) than for the control lacon (2.23).

As a result, from a health point of view, the $\mathrm{P} / \mathrm{S}$, $\mathrm{n} 6 / \mathrm{n} 3$ and $\mathrm{h} / \mathrm{H}$ ratios revealed that the lacon obtained from animals fed with chestnuts (with 15 and 25\% inclusion of chestnut in the diet) was healthier than lacon from animals fed a commercial feed.

\subsection{Principal components and discriminate analysis}

\subsubsection{Factor analysis using principal component}

The objective of this factor analysis (FtA) was to obtain a reduced number of principal components which would explain the variability of the selected compounds. When this data set was used (20 parameters), the first four principal components were chosen $(94.16 \%$ of the total variance) because the eigenvalues were higher than 1 , and therefore, they explain a higher percentage of variance than each original variable. All variables presented communality higher than 0.824 , which indicates that they were well represented by the four factors. A varimax rotation was carried out to minimize the number of variables that influence each fatty acid, and then, to facilitate the interpretation of the results. The first principal component $(\mathrm{PC} 1)$ that explained the higher percentage of variance $(28.29 \%)$ was positively associated with $\mathrm{C} 17: 1 \mathrm{n} 7, \mathrm{C} 18: 2 \mathrm{n} 6, \mathrm{C} 18: 3 \mathrm{n} 3$, PUFA, $\Sigma \mathrm{n} 3, \Sigma \mathrm{n} 6$ and P/S ratio and negatively correlated with C18:0 (Figure 1). The PC2 that explained the $26.60 \%$ of the total variance was positively related to the $\mathrm{h} / \mathrm{H}$ ratio and nutritive value and negatively linked to C16:0, SFA and the $\Sigma \mathrm{n} 6 / \Sigma \mathrm{n} 3$ ratio. The PC3 explained $25.47 \%$ of the total variance and was positively correlated to C15:0, C20:3n 3 ,

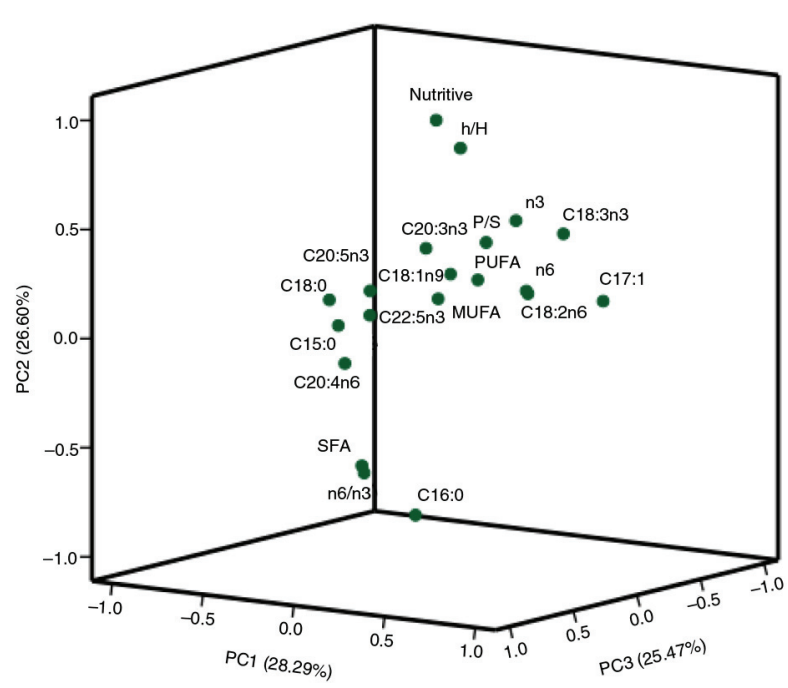

Figure 1. Projection of the variables in the rotated space defined by the first three principle components. 


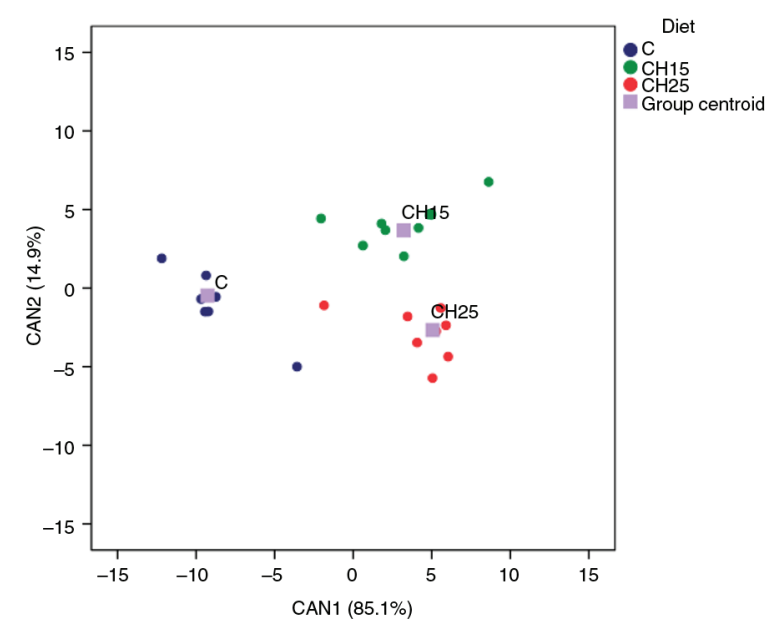

FIGURE 2. Score plot on the plane of two CAN discriminant functions obtained to predict the type of diet.

C20:5n3, C22:4n 3 and C22:5n3. Finally, the PC4 which explained $13.79 \%$ of the total variance was negatively linked to C18:1n9 and MUFA contents. Figure 1 shows the projection of the variables in the rotated space defined by the first three principle components.

\subsubsection{Discriminant analysis}

Using a new matrix of data integrated by the standardized reduced original variables, which were selected from the previous FtA, a canonical discriminant analysis (CDA) was developed (Figure 2).
This data set was subjected to the CDA according to the diet (C, CH15 and $\mathrm{CH} 25)$. The leave-one-out cross validation was used to validate the results. Table 3 shows the classification parameters such as number of eigenvalue and canonical correlation. These classification results revealed a correct aggregation for the first two discriminant factors defined. From the data set (20 parameters chosen after FtA) subjected to discriminant analysis, 4 variables $(\mathrm{C} 17: 1 \mathrm{n} 7$, C20:3n3, C20:5n3 and C22:5n3) were retained at the end of the stepwise discriminant analysis and were linearly combined to form canonical discriminant functions. When chestnut was presented in the diet in different proportions $(\mathrm{CH} 15$ and $\mathrm{CH} 25$ groups) it was still possible to discriminate among groups.

When results obtained from function discriminant functions of classification (CAN1) were plotted against results obtained from function CAN2 on axes of coordinates for each meat sample, a good discrimination among groups according to the diet was observed (see Fig 2). The first two CAN accounted together for $100 \%$ of the total variance, with the first CAN (CAN1) explaining 85.1\% of total variability and the second CAN (CAN2) explaining the remaining $14.9 \%$ of total variability. The CAN1 variable allowed segregation of the C samples from the $\mathrm{CH} 15$ and $\mathrm{CH} 25$ ones, while the CAN2 allowed segregation of the $\mathrm{CH} 15$ from the CH25 lacon (Fig. 2). After cross-validation, the discriminant analysis correctly attributed each lacon to its original group with an accuracy of $87.5 \%$ for the $\mathrm{C}$ group and of $87.5 \%$ and $75 \%$ for $\mathrm{CH} 15$ and $\mathrm{CH} 25$ groups, respectively.

TABLE 3. CAN classification parameters and results according to diet (C, $\mathrm{CH} 15$ and $\mathrm{CH} 25)$

\begin{tabular}{|c|c|c|c|c|c|c|}
\hline \multicolumn{7}{|c|}{ Data set (20 parameters chosen after FtA) } \\
\hline \multicolumn{7}{|c|}{ Eigenvalues } \\
\hline Function & Eigenvalue & $\begin{array}{c}\% \text { of } \\
\text { Variance }\end{array}$ & Cumulative \% & $\begin{array}{l}\text { Canonic } \\
\text { correlati }\end{array}$ & & \\
\hline 1 & $48.876^{\mathrm{a}}$ & 85.1 & 85.1 & 0.990 & & \\
\hline 2 & $8.556^{\mathrm{a}}$ & 14.9 & 100.0 & 0.946 & & \\
\hline \multicolumn{7}{|c|}{ Classification results $^{b}$} \\
\hline & & & \multicolumn{3}{|c|}{ Predicted group membership } & \\
\hline & & Diet & $\mathbf{C}$ & CH15 & CH25 & Total \\
\hline \multirow[t]{6}{*}{ Cross-validated $^{\text {a }}$} & Count & $\mathrm{C}$ & 7 & 0 & 1 & 8 \\
\hline & & $\mathrm{CH} 15$ & 0 & 7 & 1 & 8 \\
\hline & & $\mathrm{CH} 25$ & 0 & 2 & 6 & 8 \\
\hline & $\%$ & $\mathrm{C}$ & 87.5 & 0.0 & 12.5 & 100.0 \\
\hline & & $\mathrm{CH} 15$ & 0.0 & 87.5 & 12.5 & 100.0 \\
\hline & & $\mathrm{CH} 25$ & 0.0 & 25.0 & 75.0 & 100.0 \\
\hline
\end{tabular}

C: concentrate feeding (control); $\mathrm{CH} 15$ : concentrate feed containing $15 \%$ dried chestnuts; $\mathrm{CH} 25$ : concentrate feed containing $25 \%$ dried chestnuts; ${ }^{\text {a }}$ Cross validation is done only for those cases in the analysis. In cross validation, each case is classified by the functions derived from all cases other than that case; ${ }^{b} 83.3 \%$ cross-validated grouped cases correctly classified. 
According to these coefficients, the parameters which mostly accounted for the segregation of CAN1 were $\mathrm{C} 20: 3 \mathrm{n} 3$ and $\mathrm{C} 22: 5 \mathrm{n} 3$, while the variables accounting for group segregation of CAN2 were $\mathrm{C} 17: \ln 7$ and $\mathrm{C} 20: 5 \mathrm{n} 3$. As reported in Table 2, $\mathrm{C} 20: 3 \mathrm{n} 3$ and $\mathrm{C} 22: 5 \mathrm{n} 3$ contents were lower in $\mathrm{C}$ lacon samples compared to $\mathrm{CH} 15$ and $\mathrm{CH} 25$, while $\mathrm{C} 20: 5 \mathrm{n} 3$ percentages were higher in $\mathrm{CH} 25$ lacon samples compared to $\mathrm{CH} 15$ ones.

\section{CONCLUSIONS}

The inclusion of chestnuts in the formulation of feed decreases the SFA and MUFA contents in the intramuscular fat of lacon, while the total PUFA content increases (in particular n3 PUFAs). According to $\mathrm{P} / \mathrm{S}, \mathrm{n} 6 / \mathrm{n} 3$ and $\mathrm{h} / \mathrm{H}$ ratios lacon from chestnut-fed animals was healthier than those obtained from pigs fed with commercial feed. In this regard, lacon from $\mathrm{CH} 15$ and $\mathrm{CH} 25$ also had higher contents of some specific fatty acids related to health benefits (such as C18:3n3, EPA, DPA or DHA). The discriminant analysis selected 4 variables $(\mathrm{C} 17: 1 \mathrm{n} 7, \mathrm{C} 20: 3 \mathrm{n} 3, \mathrm{C} 20: 5 \mathrm{n} 3$ and $\mathrm{C} 22: 5 \mathrm{n} 3)$ and calculated two discriminating functions which allowed for prediction of the amount of chestnut in the diets. When chestnut was presented in the finishing diet (CH15 and $\mathrm{CH} 25$ groups) it was still possible to discriminate between groups. Therefore, the use of chestnuts in the diet (at both levels: 15\% and $25 \%$ of chestnuts) allow us to obtain healthier dry cured products (in this study, lacon).

\section{REFERENCES}

Association of Official Analytical Chemistry (AOAC). 2005. Official methods of analysis of AOAC International (17th ed.). Maryland, USA.

Barreira J, Ferreira I, Oliveira M, Pereira J. 2008. Antioxidant activities of the extracts from chestnut flower, leaf, skins and fruit. Food Chem. 107, 1106-1113. http://dx.doi.org/ 10.1016/j.foodchem.2007.09.030.

Bermúdez R, Franco I, Franco D, Carballo J, Lorenzo JM. 2012. Influence of inclusion of chestnut in the finishing diet on fatty acid profile of dry-cured ham from Celta pig breed. Meat Sci. 92, 394-399.

Bligh EG, Dyer WJ. 1959. A rapid method of total lipid extraction and purification. Can. J. Biochem. Phys. 37, 911-917. http://dx.doi.org/10.1139/o59-099.

British Nutrition Foundation. 1992. Unsaturated fatty acids: Nutritional and physiological significance, the report of British Nutrition Foundation's Task Force. London, United Kingdom.

Carril JA, Rivero CJ, Fernández M, Lorenzo JM. 2013. La Raza, In: CETECA (ed) Manual del Cerdo Celta, 1st edition, Spain, pp. 17-41.

Cobos Á, Veiga A, Díaz O. 2008. Influence of a diet with chestnuts and sugar beet pulp on the lipid composition of "lacóngallego" (dry cured pork foreleg). Grasas Aceites $\mathbf{5 9}$, 121-127. http://dx.doi.org/10.3989/gya.2008.v59.i2.499.

Coutron-Gambotti C, Gandemer G, Casabianca F. 1998. Effects of substituting a concentrated diet for chestnuts on the lipid traits of muscle and adipose tissues in Corsican and Corsican $\times$ Large White pigs reared in sylvo-pastoral system in Corsica. Meat Sci. 50, 163-174. http://dx.doi.org/10.1016/ S0309-1740(98)00027-8.
Díaz O, Ros C, Veiga A, Cobos A. 2009. Including chestnuts and sugar beet pulp in diets for pigs: the effects on the quality of pork meat and the sensory properties of dry-cured sausage (chorizo Gallego). J. Muscle Foods 20, 449-464. http:// dx.doi.org/10.1111/j.1745-4573.2009.00160.x.

Domínguez R, Martínez S, Gómez M, Carballo J, Franco I. 2015. Fatty acids, retinol and cholesterol composition in various fatty tissues of Celta pig breed: Effect of the use of chestnuts in the finishing diet. J. Food Compos. Anal. 37, 104-111. http://dx.doi.org/10.1016/j.jfca.2014.08.003.

Doran O, Moule SK, Teye GA, Whittington FM, Hallett KG, Wood JD. 2006. A reduced protein diet induces stearoylCoA desaturase protein expression in pig muscle but not in subcutaneous adipose tissue: relationship with intramuscular lipid formation. Brit. J. Nutr. 95, 609-617. http:// dx.doi.org/10.1079/BJN20051526.

Fernández M, Ordóñez JA, Cambero I, Santos C, Pin C, de la Hoz L. 2007. Fatty acid compositions of selected varieties of Spanish dry ham related to their nutritional implications. Food Chem. 101, 107-112. http://dx.doi.org/10.1016/j. foodchem.2006.01.006.

Gonçalves B, Borges O, Soares Costa H, Bennett R, Santos M, Silva AP. 2010. Metabolite composition of chestnut (Castanea sativa Mill.) upon cooking: Proximate analysis, fibre, organic acids and phenolics. Food Chem. 122, 154-160. http://dx doi.org/10.1016/j.foodchem.2010.02.032.

Gondret F, Guitton N, Guillerm-Regost C, Louveau I. 2008. Regional differences in porcine adipocytes isolated from skeletal muscle and adipose tissues as identified by a proteomic approach. J. Anim. Sci. 86, 2115-2125. http://dx.doi. org/10.2527/jas.2007-0750.

Kloareg M, Le Bellego L, Mourot J, Noblet J, Van Milgen J. 2005. Deposition of dietary fatty acids and of de novo synthetized fatty acids in growing pigs: effects of high ambient temperature and feeding restriction. Brit. J. Nutr. 93, 803-811. http://dx.doi.org/10.1079/BJN20051420.

Lopez-Huertas E. 2010. Health effects of oleic acid and long chain omega-3 fatty acids (EPA and DHA) enriched milks. A review of intervention studies. Pharmacol. Res. 61, 200-207. http://dx.doi.org/10.1016/j.phrs.2009.10.007.

Lorenzo JM, Montes R, Purriños L, Cobas N, Franco D. 2012. Fatty acid composition of Celta pig breed as influenced by sex and location of fat in the carcass. J. Sci. Food Agric. 92, 1311-1317. http://dx.doi.org/10.1002/jsfa.4702.

Lorenzo JM, Carballo J, Franco D. 2013. Effect of the inclusion of chestnut in the finishing diet on volatile compounds of dry-cured ham from Celta pig breed. J. Integr. Agric. 12, 2002-2012. http://dx.doi.org/10.1016/S20953119(13)60638-3.

Lorenzo JM, Franco D, Carballo J. 2014. Effect of the inclusion of chestnut in the finishing diet on volatile compounds during the manufacture of dry-cured "Lacón" from Celta pig breed. Meat Sci. 96, 211-223. http://dx.doi.org/10.1016/j. meatsci.2013.07.007.

Micha R, Mozaffarian D. 2010. Saturated fat and cardiometabolic risk factors, coronary heart disease, stroke, and diabetes: a fresh look at the evidence. Lipids 45, 893-905. http:// dx.doi.org/10.1007/s11745-010-3393-4.

Mitchaothai J, Yuangklang C, Wittayakun S, Vasupen K, Wongsutthavas S, Srenanul P, Hovenier R, Everts H, Beynen AC. 2007. Effect of dietary fat type on meat quality and fatty acid composition of various tissues in growingfinishing swine. Meat Sci. 76, 95-101. http://dx.doi.org/ 10.1016/j.meatsci.2006.10.017.

Morrison WR, Smith LM. 1964. Preparation of fatty acid methyl esters and dimethylacetals from lipids with boron fluoride-methanol. J. Lipid Res. 5, 600-608.

Official Journal of the European Communities. 2001. Commission Regulation (EC) No 898/2001, of 7 May 2001. L 126, Vol. 44, pp. 18.

Official Journal of the European Communities. 2010. Official Journal of the European Communities Commission Regulation (EC) No 409/2010, of 11 May 2010. L 118, Vol. 53, pp. 6.

Pereira-Lorenzo S, Ramos-Cabrer AM, Díaz-Hernández MB, Ciordia-Ara M, Ríos-Mesa D. 2006. Chemical composition 
of chestnut cultivars from Spain. Sci. Hort. 107, 306-314. http://dx.doi.org/10.1016/j.scienta.2005.08.008.

Pugliese C, Sirtori F, Acciaioli A, Bozzi R, Campodoni G, Franci O. 2013. Quality of fresh and seasoned fat of Cinta Senese pigs as affected by fattening with chestnut. Meat Sci. 93, 92-97. http://dx.doi.org/10.1016/j.meatsci.2012.08.006.

Purriños L, Bermúdez R, Franco D, Carballo J, Lorenzo JM. 2011. Development of volatile compounds during the manufacture of dry-cured "lacon" a Spanish traditional meat product. J. Food Sci. 76, C89-C97. http://dx.doi.org/ 10.1111/j.1750-3841.2010.01955.x.

Real Decreto 2129/2008, de 26 de diciembre, por el que se establece el Programa nacional de conservación, mejora y fomento de las razas ganaderas. $\left(\mathrm{BOE} \mathrm{n}^{\circ} 23\right.$, de 27 de enero de 2009).

Raes K, De Smet S, Demeyer D. 2004. Effect of dietary fatty acids on incorporation of long chain polyunsaturated fatty acids and conjugated linoleic acid in lamb, beef and pork meat: a review. Anim Feed Sci. Tech. 113, 199-221. http:/l dx.doi.org/10.1016/j.anifeedsci.2003.09.001.

Rey AI, López-Bote CJ, Kerry JP, Lynch PB, Buckley DJ, Morrissey PA. 2004. Modification of lipid composition and oxidation in porcine muscle and muscle microsomes as affected by dietary supplementation of $n-3$ with either n-9 or n- 6 fatty acids and $\alpha$-tocopheryl acetate. Anim. Feed Sci. Tech. 113, 223-238. http://dx.doi.org/10.1016/j. anifeedsci.2003.08.007.
Santos-Silva J, Mendes IA, Bessa RJB. 2002. The effect of genotype, feeding system and slaughter weight on the quality of light lambs: 1. Growth, carcass composition and meat quality. Livest Prod. Sci. 76, 17-25. http://dx.doi. org/10.1016/S0301-6226(01)00334-7.

Sierra V, Aldai N, Castro P, Osoro K, Coto-Montes A, Oliván M. 2008. Prediction of the fatty acid composition of beef by near infrared transmittance spectroscopy. Meat Sci. 78, 248-255. http://dx.doi.org/10.1016/j.meatsci.2007.06.006.

Simopoulos AP. 2004. Omega-6/omega-3 essential fatty acid ratio and chronic diseases. Food Rev. Int. 20, 77-90. http:// dx.doi.org/10.1081/FRI-120028831.

Temperan S, Lorenzo JM, Castiñeiras BD, Franco I, Carballo J. 2014. Carcass and meat quality traits of Celta heavy pigs. Effect of the inclusion of chestnuts in the finishing diet. Spanish J. Agric. Res. 12, 694-707. http://dx.doi.org/ 10.5424/sjar/2014123-5057.

Teye GA, Sheard PR, Whittington FM, Nute GR, Stewart A, Wood JD. 2006. Influence of dietary oils and protein level on pork quality. 1. Effects on muscle fatty acid composition, carcass, meat and eating quality. Meat Sci. 73, 157-165. http://dx.doi.org/10.1016/j.meatsci.2005.11.010.

UK Department of Health. 1994. Nutritional aspects of cardiovascular disease. Report on health and social subject no. 46. London, United Kingdom 